\title{
Assessment of the Size of Sella Turcica among Nepalese Population by Computed Tomography
}

\author{
Makaju G, Joshi BR, Chand RB \\ Department of Radiology, TU Teaching Hospital, Maharajgunj, Kathmandu, Nepal \\ Received: September 2, 2019 \\ Accepted: November 30, 2019 \\ Published: December 31, 2019 \\ Cite this paper: \\ Makaju G, Joshi BR, Chand RB. Assessment of the Size of Sella Turcica among Nepalese Population by Computed \\ Tomography. Nepalese Journal of Radiology 2019;9(14):40-47.http://dx.doi.org/10.3126/njr.v9i2.27429
}

\begin{abstract}
Introduction: The deformity of the sella turcica is often a major clue that an abnormality exists within the cranium, hence a familiarity with the sella turcica anatomy and radiological appearance is important. The aim of this study was to assess the dimension of sella turcica of normal Nepalese people by using computed tomography scan of head and to correlate the dimension with the patient's age and gender.
\end{abstract}

Methods: This prospective study was performed in a tertiary hospital in Kathmandu. Data were collected over the period of 4 months from June to September 2018 with the total of 73 patients who underwent CT of head. The age and gender of the patients were noted. The dimensions of sella turcica were measured at the predefined three directions: length, depth and antero-posterior diameter of the sella turcica.

Results: The sella turcica had a mean length of $8.375 \mathrm{~mm}$, AP diameter of $7.029 \mathrm{~mm}$, and depth of $10.13 \mathrm{~mm}$. The dimensions of the sella turcica increased with age till the age of 80 years and then decreased.

Conclusions: This study concluded that the length, AP diameter and depth of the sella turcica vary with respect to age group. The length and depth of sella turcica were higher in males while AP diameter in females.

Keywords: Cranium; Sella Turcica; Skull

\section{INTRODUCTION}

The deformity of the sella turcica is often a major clue that an abnormality exists within the cranium, hence a familiarity with the sella turcica anatomy and radiological appearance is important. ${ }^{1}$ One of the clinical significance of the sella turcica is the empty sella syndrome

Correspondence to: Dr. Birendra Raj Joshi

Department of Radiology which is the condition of a shrunken or flattened pituitary gland. ${ }^{2,3}$

TU Teaching Hospital, Maharajgunj

Kathmandu, Nepal

Email: swasulav@gmail.com 
The sella turcica also known as hypophyseal fossa is a saddle shaped depression in the body of the sphenoid bone in the human skull that houses the pituitary gland; it is a cephalometric landmark in the skull. ${ }^{4}$ Anatomically, it is located in the sphenoid bone behind the chiasmatic groove and the tuberculum sellae situated within the middle cranial fossa and on a lateral skull radiograph, the image of the sella turcica is U-shape. ${ }^{5}$ Any abnormality of the pituitary gland could manifest from an altered shape of sella turcica, to disturbance in regulation of secretion of glandular hormones. ${ }^{6}$ Also, a deviation from the normal size and shape of the sella turcica due to its malformation may be implicated in an undetected underlying disease and it can be an indication of a pathological condition of the gland. ${ }^{7,8}$ The anatomy of the sella turcica varies in size and shape; it has been classified into three types: round, oval and flat. ${ }^{9}$ The floor of the sella turcica, which in most cases is concave, may be flat or even convex. ${ }^{10}$ The sella turcica is usually demarcated by a dense, thin white line in lateral radiographs. It is sometimes more important to recognize this feature than to estimate the size of the fossa. ${ }^{11}$ Many studies have reported several changes in the size of the sella turcica in various pathological conditions such as Down syndrome, Williams's syndrome, Sickle disease and lumbosacral myelomeningocele. The present study made use of lateral Computed Tomography images of the skull was undertaken to establish the normal dimensions of sella turcica in Nepalese population with a view to establish whether the size of the sella turcica vary with age and gender.

The result of this study will provide a base line data on the normal size of the sella turcica for this population, which could be of assistance in the evaluation and detection of pathological conditions of the sella turcica.

\section{METHODS}

This cross sectional prospective study was performed in a tertiary hospital in Kathmandu. Data were collected over the period of 4 months from June to September 2018 with the total of 73 patients who underwent CT of head. Siemens Somatom Definition AS+ machine was used. Patients having pathological conditions like Down syndrome, Williams syndrome, Sickle disease, lumbosacral myelomeningocele, associated hypopituitarism and dwarfism with small sella turcica were excluded.

The age and gender of the patients were noted. The dimensions of sella turcica were measured at the predefined three directions: length, depth and antero-posterior diameter of the sella turcica. The normal size of the sella turcica was measured by tracing the contour of the pituitary fossa from the tip of the dorsum sellae to the turberculum sellae and then following a straight line from the turberculum sellae back to the origin. This corresponds to the position of the diaphragmatic sellae. The length of the sella turcica was measured as the distance from the turberculum sella to the tip of the dorsum sellae, and the depth of sella turcica was measured perpendicular to this line to the deepest point on the floor.

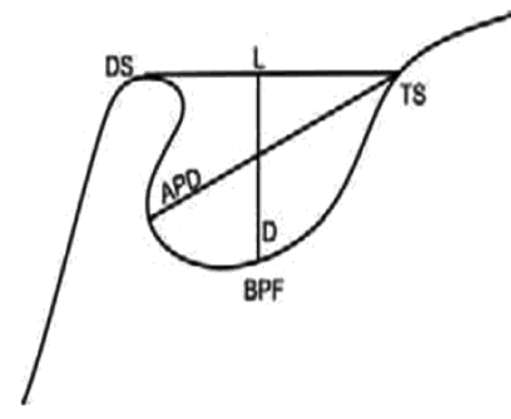

Figure 1: Illustration of normal morphology of sella turcica $(T S=$ Turberculum Sellae, $D S=$ Dorsum Sellae, BPF = Base of pituitary fossa).

According to Silverman et al. ${ }^{12,13}$ the following lines in the above diagram were measured 
to determine the size of the sella turcica; the reference lines used were situated in the midsagittal plane.

A) The Length: was obtained by measuring the distance from the tuberculum sellae to the tip of dorsum sellae.

B) The Depth: was obtained by measuring a perpendicular from the line mentioned above to the deepest point on the floor of the fossa.

C) The Antero-posterior Greatest Diameter: was obtained by measuring from the tuberculum sellae to the furthest point on the posterior inner wall of the fossa, below the dorsum sellae.

Multiple planar reconstructions were generated on a view workstation (Siemens Medical Systems). The slices were manually adjusted for mid sagittal section of the brain in bone window with sharp resolution. The dimensions were measured with an electronic caliper. Data were analyzed using SPSS Windows Version 20. Descriptive statistics of Mean \pm Standard error of mean (S. E. M) were used to summarize the data obtained. Two-sided $P$ values were calculated using the Paired sample T-test for observed variables. $\mathrm{P}$ values $<0.05$ were considered statistically significant.

\section{RESULTS}

The sample consisted of 73 subjects; 33 female (45.2\%) and 40 male (54.8\%). The samples were classified according to the age from $<10$ to $>81$, as presented in Table 1 . Data were presented as mean and standard deviation for all variables. Detailed results are shown in the tables and figures below. ( Figure 2)

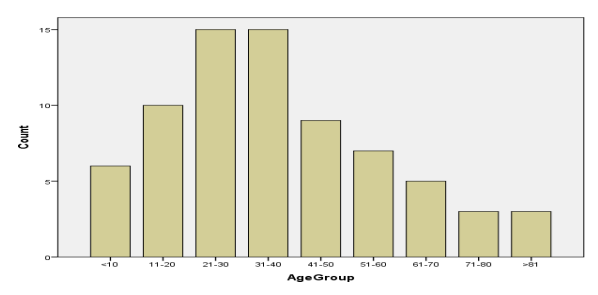

Figure 2: Bar chart of the distribution of sample size according to the age group.
Table 1: Distribution of sample size according to age group

\begin{tabular}{|c|c|c|}
\hline Age group & Frequency & Percentage \\
\hline $\mathbf{1 1 0}$ & 6 & 8.2 \\
\hline $\mathbf{1 1 - 2 0}$ & 10 & 13.7 \\
\hline $\mathbf{2 1 - 3 0}$ & 15 & 20.5 \\
\hline $\mathbf{3 1 - 4 0}$ & 15 & 20.5 \\
\hline $\mathbf{4 1 - 5 0}$ & 9 & 12.3 \\
\hline $\mathbf{5 1 - 6 0}$ & 7 & 9.6 \\
\hline $\mathbf{6 1 - 7 0}$ & 5 & 6.8 \\
\hline $\mathbf{7 1 - 8 0}$ & 3 & 4.1 \\
\hline$>\mathbf{8 1}$ & 3 & 4.1 \\
\hline Total & 73 & 100 \\
\hline
\end{tabular}

Table 2: Calculation of mean and standard deviation of Age, Length, AP diameter and Depth of the sella turcica.

\begin{tabular}{|l|l|l|l|}
\hline \multicolumn{1}{|c|}{ Variables } & $\mathbf{N}$ & Mean & $\begin{array}{c}\text { Std. Devia- } \\
\text { tion }\end{array}$ \\
\hline Age & 73 & 38 & 20.76 \\
\hline Length & 73 & 0.8375 & 0.20115 \\
\hline AP diameter & 73 & 0.7029 & 0.13183 \\
\hline Depth & 73 & 1.0130 & 0.20219 \\
\hline
\end{tabular}

The length, AP diameter and depth for female subjects were $0.8267 \mathrm{~cm}, 0.7112 \mathrm{~cm}$ and $1.0021 \mathrm{~cm}$ respectively where as these measured $0.8465 \mathrm{~cm}, 0.6961 \mathrm{~cm}$ and $1.02202 \mathrm{~cm}$ for male subjects. (Table 3 )

Table 3: Mean and Standard deviation of Length. AP diameter, and Depth of sella turcica with respect to gender.

\begin{tabular}{|l|l|l|l|l|}
\hline \multicolumn{2}{|c|}{ Gender } & $\begin{array}{c}\text { Length } \\
{[\mathrm{cm}]}\end{array}$ & $\begin{array}{c}\text { AP } \\
\text { diameter } \\
(\mathrm{cm})\end{array}$ & $\begin{array}{c}\text { Depth } \\
(\mathrm{cm})\end{array}$ \\
\hline \multirow{2}{*}{ Female } & Mean & 0.8267 & 0.7112 & 1.0021 \\
\cline { 2 - 5 } & SD & 0.16378 & 0.12978 & 0.18854 \\
\hline \multirow{2}{*}{ Male } & Mean & 0.8465 & 0.6961 & 1.0220 \\
\cline { 2 - 5 } & SD & 0.22914 & 0.13476 & 0.21475 \\
\hline \multirow{2}{*}{ Total } & Mean & 0.8375 & 0.7029 & 1.0130 \\
\cline { 2 - 5 } & SD & 0.20115 & 0.13183 & 0.20219 \\
\hline
\end{tabular}


The length of sella turcica was found to be highest for the age group of 71-80 years measuring $1.1167 \mathrm{~cm}$ and lowest for the age group less than 10 years measuring $0.7276 \mathrm{~cm}$. The AP diameter was found to be highest for the age group of 71-80 years measuring $0.87 \mathrm{~cm}$ and lowest for the age group of less than 10 years measuring $0.5067 \mathrm{~cm}$. The depth is highest for the age group of 71-80 years measuring $1.42 \mathrm{~cm}$ and lowest for age group less than 10 years measuring $0.7517 \mathrm{~cm}$. (Table 4).

Correlation between Age, Length, AP diameter and Depth of the sella turcica and paired sample t-test between all the variables are shown in table $5 \& 6$.

Table 4: Mean and standard deviation of length, AP diameter and depth of sella turcica with respect to age group.

\begin{tabular}{|c|c|c|c|c|}
\hline \multicolumn{2}{|c|}{ Age Group } & Length[cm] & $\begin{array}{c}\text { AP } \\
\text { diameter }[\mathrm{cm}]\end{array}$ & Depth[cm] \\
\hline \multirow{2}{*}{$<10$} & Mean & .7267 & .5067 & .7517 \\
\hline & Std. Deviation & .08501 & .07891 & .06524 \\
\hline \multirow{2}{*}{$11-20$} & Mean & .7520 & .5970 & .8820 \\
\hline & Std. Deviation & .15605 & .09044 & .12506 \\
\hline \multirow{2}{*}{ 21-30 } & Mean & .8253 & .7707 & 1.0167 \\
\hline & Std. Deviation & .16080 & .09369 & .13468 \\
\hline \multirow{2}{*}{$31-40$} & Mean & .8513 & .7117 & 1.1087 \\
\hline & Std. Deviation & .27034 & .10145 & .25139 \\
\hline \multirow{2}{*}{$41-50$} & Mean & .8211 & .7067 & 1.0300 \\
\hline & Std. Deviation & .19029 & .09670 & .13000 \\
\hline \multirow{2}{*}{$51-60$} & Mean & .8729 & .7371 & .9914 \\
\hline & Std. Deviation & 1.3187 & 1.2958 & 0.9026 \\
\hline \multirow{2}{*}{$61-70$} & Mean & .9040 & .7500 & 1.0160 \\
\hline & Std. Deviation & .25442 & .17088 & .10668 \\
\hline \multirow{2}{*}{$71-80$} & Mean & 1.1167 & .8700 & 1.4200 \\
\hline & Std. Deviation & .25166 & .17321 & .29462 \\
\hline \multirow{2}{*}{$>81$} & Mean & .9133 & .7300 & 1.0633 \\
\hline & Std. Deviation & .16862 & .06557 & .07095 \\
\hline \multirow{2}{*}{ Total } & Mean & .8375 & .7029 & 1.0130 \\
\hline & Std. Deviation & .20115 & .13183 & .20219 \\
\hline
\end{tabular}


Table 5: Correlation between Age, Length, AP diameter and Depth of the sella turcica.

\begin{tabular}{|l|l|l|l|l|l|}
\hline \multirow{2}{*}{ Age } & $\begin{array}{l}\text { Pearson correla- } \\
\text { tion }\end{array}$ & 1 & $.332^{* *}$ & $.423^{* *}$ & $.447^{* *}$ \\
\cline { 2 - 6 } & Sig. (2-tailed) & & .004 & .000 & .000 \\
\hline \multirow{2}{*}{ Length } & $\begin{array}{l}\text { Pearson correla- } \\
\text { tion }\end{array}$ & $.332^{* *}$ & 1 & $.336^{* *}$ & $.472^{* *}$ \\
\cline { 2 - 6 } & Sig. (2-tailed) & .004 & & .004 & .000 \\
\hline \multirow{2}{*}{$\begin{array}{l}\text { AP diam- } \\
\text { eter }\end{array}$} & $\begin{array}{l}\text { Pearson correla- } \\
\text { tion }\end{array}$ & $.423^{* *}$ & $.336^{* *}$ & 1 & $.581^{* *}$ \\
\cline { 2 - 6 } & Sig. (2-tailed) & .000 & .004 & .000 \\
\hline \multirow{2}{*}{ Depth } & $\begin{array}{l}\text { Pearson correla- } \\
\text { tion }\end{array}$ & $.447^{* *}$ & $.472^{* *}$ & $.581^{* *}$ & 1 \\
\cline { 2 - 6 } & Sig. (2-tailedd) & .000 & .000 & .000 & \\
\hline
\end{tabular}

**. Correlation is significant at the 0.01 level (2-tailed).

Table 6: Paired sample t- test between all variables.

\begin{tabular}{|c|c|c|c|c|c|c|c|c|c|}
\hline & \multirow{3}{*}{ Mean } & \multicolumn{5}{|c|}{ Paired Differences } & & \multirow{3}{*}{ df } & \multirow{3}{*}{$\begin{array}{c}\text { Sig. } \\
\text { (2-tailed) }\end{array}$} \\
\hline & & \multirow{2}{*}{$\begin{array}{l}\text { Std. } \\
\text { Devia- } \\
\text { tion }\end{array}$} & \multirow{2}{*}{$\begin{array}{l}\text { Std. } \\
\text { Error } \\
\text { Mean }\end{array}$} & \multicolumn{2}{|c|}{$\begin{array}{l}95 \% \text { Confidence } \\
\text { Interval of the } \\
\text { Difference }\end{array}$} & & & & \\
\hline & & & & Lower & Upper & & & & \\
\hline $\begin{array}{c}\text { Pair } \\
1\end{array}$ & $\begin{array}{l}\text { Length - } \\
\text { AP diam- } \\
\text { eter }\end{array}$ & .13459 & .20001 & .02341 & .08792 & .18125 & 5.749 & 72 & .000 \\
\hline $\begin{array}{c}\text { Pair } \\
2\end{array}$ & $\begin{array}{l}\text { AP diame- } \\
\text { ter - Depth }\end{array}$ & -.31007 & .16527 & .01934 & -.34863 & -.27151 & -16.030 & 72 & .000 \\
\hline $\begin{array}{c}\text { Pair } \\
3\end{array}$ & $\begin{array}{l}\text { Depth - } \\
\text { Length }\end{array}$ & .17548 & .20726 & .02426 & .12712 & .22384 & 7.234 & 72 & .000 \\
\hline
\end{tabular}

The scatter plot diagrams showed the high positive correlation between age and dimensions of the sella turcica. ( Figures 3, 4, 5) 


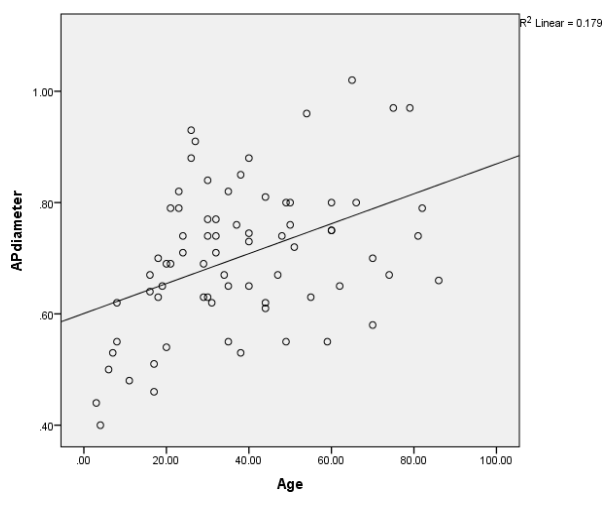

Figure 3: Scatter plot diagram of Anteroposterior diameter of sella turcica and age.

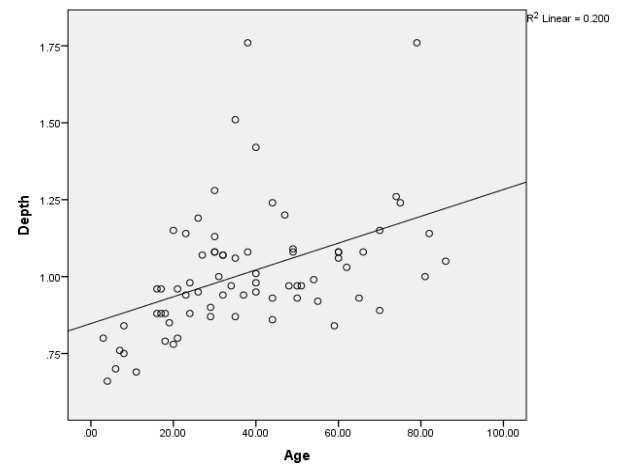

Figure 4: Scatter plot diagram of the depthof sella turcica and age.

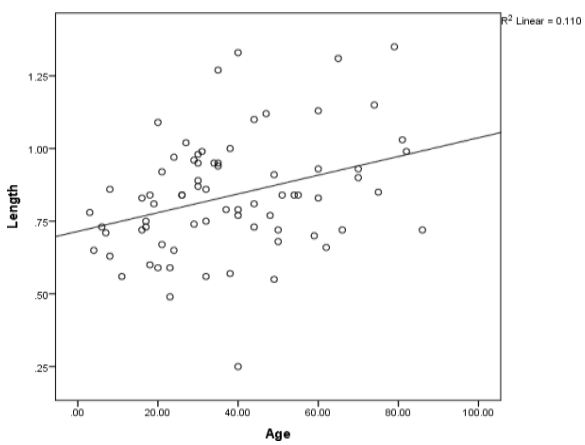

Figure 5: Scatter plot diagram of length of sella turcica and age.

\section{DISCUSSION}

The present study investigated the normal dimensions of the sella turcica and the relationship with gender and age in Nepalese population, using computed tomography of patients who underwent $\mathrm{CT}$ head examination. There was a statistically significant difference between the dimensions of the sella turcica. Sella turcica dimensions reported by many researchers were based on Caucasian populations and the data were mostly obtained from skull radiographs. ${ }^{11,15}$ Based on our investigation, it was observed that, this was the first time the sella turcica being investigated by computed tomography in Nepalese population. Comparing the values from the study with that of Zegga who reported values of length $11.4 \mathrm{~mm}$, depth $9.3 \mathrm{~mm}$ and antero- posterior diameter 14.0 $\mathrm{mm}$; it was obvious that the values of our study were less. ${ }^{14}$ This difference could be due to the radiographic method. Similar pattern was noted by Asad et al. ${ }^{16}$ who reported that the mean length of sella turcica of $14.9 \mathrm{~mm}$. Axelsson et al. ${ }^{17}$ reported linear dimension (antero-posterior diameter) even larger than the values reported by Zegga. Kantor conducted a study in 1999 with sample of 325 orthodontic patients, varying from 6 to 49 years with mean age of 14.8 years. They measured linear dimensions of sella turcica on the lateral cephalogram. The antero-posterior diameter ranged from 6.0 to $17.0 \mathrm{~mm}$, mean value was found to be $10.9 \pm 1.8 \mathrm{~mm}$, while the depth varied from 2.5 to $12.5 \mathrm{~mm}$ with a mean of $7.6 \pm 1.7 \mathrm{~mm}^{7}$

There was a significant correlation of mean length, antero-posterior diameter and depth of the sella turcica with the age of the individuals. The study done by Nagaraj et al. ${ }^{18}$ confirmed that the depth and AP diameter gradually increased with age, however length showed no significant increase. The outcome of our study concluded that the all the dimensions of the sella turcica increased with age till the age of 80 years and then decreased.

Our study concluded there was no significant difference in the size with gender. Ogunnaike et al. ${ }^{19}$ concluded that the males tend to have slightly larger sella turcica dimensions than the females. The study done by Arshiya S et al. found no difference in the size of sella turcica between males and females. ${ }^{21}$

Our study used the computed tomography which gave a more exact impression of 
anatomical features thereby avoiding this drawback associated with the radiographic method. The values reported were lower than those reported in Caucasian studies. The sample size was not adequate to generalize the result.

The size of pituitary gland can be roughly estimated from the dimensions of sella turcica obtained in pathological conditions since disease conditions of the pituitary ultimately affect the size of the sella turcica. CT and MRI give more accurate values than radiographic method and in this regard, the sella turcica has a "largely constant dimensions" except in pathological conditions. It is recommended that further investigations should be carried out on the assessment of the possible correlations between sella turcica dimensions and cephalometric parameters and variations in sella turcica dimensions among the various ethnic groups.

\section{CONCLUSIONS:}

The sella turcica has a mean length of $8.375 \mathrm{~mm}$, AP diameter of $7.029 \mathrm{~mm}$, and depth of $10.13 \mathrm{~mm}$. This study concluded that the length, AP diameter and depth of the sella turcica vary with respect to age group. The length and depth of sella turcica were higher in males while AP diameter in females.

\section{CONFLICT OF INTEREST}

None

\section{SOURCES OF FUNDING}

None

\section{REFERENCES}

1. Meschan I. An atlas of anatomy basic to radiology. WB Saunders Company; 1975.

2. Tekiner H, Acer N, Kelestimur F. Sella turcica: an anatomical, endocrinological, and historical perspective. Pituitary
2015;18(4):575-578. https://doi. org/10.1007/s11102-014-0609-2

3. Agarwal JK, Sahay RK, Bhadada SK, Reddy VS, Agarwal NK. Empty sella syndrome. J Indian Acad Clin Med 2001;2(3):198-202. Available from: https://pdfs.semanticscholar.org/2d1f/8 ea064d7282e59d66282053e582d4cd24 de0.pdf [Accessed 1st June 2019].

4. Saokar C. Assessment of Sella Turcica Morphology and Dimensions In An Indian Population. J. Appl. Res. 2014;4(10):54-59. Available from: https://www.researchgate.net/ publication/314448361_The_Size_and Morphology_of_Sella_Turcica_in Different_Skeletal_Patterns_among South_Indian_Population_A_Lateral Cephalometric_Study [Accessed 3rd December 2018].

5. Mancall EL, Brock DG. Cranial fossae. Gray's Clinical Anatomy. Elsevier Health Sciences 2011:154.

6. Saokar PC, Nawal S. The Comparative Study of Size of Sella Turcica in Different Skeletal Types In Local Population-An In Vitro Study. Indian J. Appl. Res 2014;4(10):160-

162. Available from: https://www. worldwidejournals.com/indian-journalof-applied-research-(IJAR)/fileview/ October_2014_1492781105_49.pdf [Accessed 5th December 2018].

7. Kantor ML, Norton LA. Normal radiographic anatomy and common anomalies seen in cephalometric films. Am $J$ Orthod Dentofacial Orthop 1987;91(5):414-426. https://doi. org/10.1016/0889-5406(87)90394-5

8. Bruneton JN, Drouillard JP, Sabatier JC, Elie GP, Tavernier JF. Normal Variants of the Sella Turcica: Comparison of Plain Radiographs and Tomograms in 200 Cases. Radiology 1979;131(1):99104. https://doi.org/10.1148/131.1.99

9. Romans GJ. Cunningham's Manual of Practical Anatomy, Volume Three Head 
and Neck and Brain.

10. Camp JD. The normal and pathologic anatomy of the sella turcica as revealed at necropsy. Radiology 1923;1(2):65-73. https://doi.org/10.1148/1.2.65

11. Russell BG, Kjær I. Postnatal structure of the sella turcica in Down syndrome. Am. J. Med. Genet 1999.19;87(2):183-188. https://doi.org/10.1002/(SICI)10968628(19991119)87:2\%3C183::AIDAJMG11\%3E3.0.CO;2-A

12. Silverman PM, Kalender WA, Hazle JD. Common terminology for single and multislice helical CT. Am J Roengenol 2001;176(5):1135-1136. $\quad$ https://doi. org/10.2214/ajr.176.5.1761135

13. Silverman FN. Roentgen standards fosize of the pituitary fossa from infancy through adolescence. Am J Roentgenol Radium TherNucl Med. 1957;78(3):451460. Available from: https://www. ncbi.nlm.nih.gov/pubmed/13458563 [Accessed 16th October 2018].

14. Zagga A, Ahmed H, Trados AA, Saidu SA. Description of the normal variants of the anatomical shapes of the sella turcica using plain radiographs: experience from Sokoto, Northwestern Nigeria. Annals of African medicine 2008;7(2):7781. $\quad$ https://doi.org/10.4103/1596$\underline{3519.55676}$

15. DiChiro $\mathrm{G}$, Nelson KB. The volume of the sella turcica. Am J Roentgenol Radium Ther Nucl Med 1962;87:9891008. Available from: https://www. ncbi.nlm.nih.gov/pubmed/13885978 [Accessed 18th June 2019].

16. Asad S, Hamid WU. Assessment and comparison of dimensions of Sella turcica in skeletal class I and skeletal class II cases. Pakistan Oral and Dental Journal 2005:59-64. Available from: $\quad$ http://podj.com.pk/archive/ Jul_2011/24-Podj.pdf [Accessed 23rd November 2018].

17. Axelsson S, Storhaug K, Kjær I. Postnatal size and morphology of the sella turcica. Longitudinal cephalometric standards for Norwegians between 6 and 21 years of age. Eur. J. Orthod 2004;26(6):597-604 https://doi. org/10.1093/ejo/26.6.597

18. Nagaraj T, Shruthi R, James L, Keerthi I, Balraj L, Goswami RD. The size and morphology of sella turcica: Alateral cephalometric study. $J$ Med Radiol Pathol Surg 2015;1:3-7. https://doi. org/10.15713/ins.jmrps.14

19. Ogunleye AJ, Olanrewaju AJ, Arowosegbe M, Omotuyi OI. Molecular docking based screening analysis of GSK3B. Bioinformation 2019;15(3):201-208. $\quad$ https://doi. org/10.11648/j.ijmi.20160403.11

20. Axelsson S, Storhaug K, Kjær I. Postnatal size and morphology of the sella turcica in Williams syndrome. Eur. J. Orthod 2004;26(6):613-621. https://doi. org/10.1093/ejo/26.6.613

21. Arshiya S, Shastri S, Patil BM, Ayesha H, Priyanka A. Evaluation of size and morphology of sella turcica. Dentomaxillofac Radiol 2017;3(2):40-43. Available from: https: //www.re searchgate.net/ publication/304375873_An Assessment_of the Size of Sella Turcica_Among_Adult_Nigerians_ Resident_in_Lagos [Accessed 15th January 2019]. 